\title{
Challenges and Generations of Biofuels: Will Algae Fuel the World?
}

\section{Yaser Dhaman1*andPallavi Roy}

${ }^{1}$ Department of Chemical Engineering, Ryerson University, Ontario, Canada

Utilisation of biomass started with the discovery of fire, when early men burnt branches to cook their food and stay warm. Although we are still utilising biomass directly through burning them, we have come far in utilising those sources of energy with improved conversions. We have been forever looking for different and more efficient sources of energy. Biofuels and oil generated from peanuts and legumes were used in the 1800 s to run farm machinery and more. The discovery of petroleum entirely revolutionised our way of life. Nowadays, it is hard to imagine life without the comforts that fossil fuels bring. However, this boon is slowly turning into one of the major problems of our time. Clearly, by burning fossil fuel we are releasing immense amounts of stored carbon back into the environment, polluting it and causing problems on global a scale. As a result, there has been a recent push to develop solutions to this problem yet maintaining our way of life.

Biofuels theoretically are one of the best approaches for finding solutions to this problem. Many nations are also bound by various international treaties to reduce emissions. All these have been pushing for increased production and utilization of biofuels. It started with converting mostly edible foods being converted to ethanol and biodiesel, which was called $1^{\text {st }}$ generation biofuels. Ethanol from corn (US) or sugarcane (Brazil) is the most common among first generation biofuels. Ethanol was first mixed with gasoline in the US in the 1990s as a replacement for Methyl-ter-butyl ether (MTBE) as an additive to oxygenate gasoline, since MTBE had issues of water contamination. Brazil and USA started investing in Ethanol following an energy crisis in the 1970s. Both countries are the major producers and consumers of ethanol biofuel generated from food crops. However, major issue with first generation fuels is the food $\mathrm{v} /$ sfuel debate. This led to focus being shifted to cellulosic biofuels in the 2000s. These are the $2^{\text {nd }}$ generation biofuels where the inedible part of food crops, agricultural wastes, wood, grasses etc. are being used to produce biofuels. Agricultural residue is very attractive due to the large amount of carbon which can be converted to fuel, and the cheap cost of the feedstock is lucrative. But the $2^{\text {nd }}$ generation biofuels are still plagued by lower yields, stopping the product from being commercially viable.

This is where the new categories of biofuels come in, often referred to as the $3^{\text {rd }}$ generation biofuels or algal biofuel. Algae produce triglycerides that can be extracted and converted in a refinery to biodiesel. Producing biodiesel from algae is widely regarded as one of the most efficient ways of generating biofuels and has great potential to replace gasoline/diesel demand in transport [1]. Algal biofuel is very attractive because[2].

- Algal fuel can be produced using freshwater, saltwater and wastewater,

- The oil is biodegradable so it is harmless to the environment if spilled.

- The bio-oil production is around $60 \%$ of the biomass much higher than the 2-3\% produced from soybean.

Not only biodiesel can be produced from Algae, but also the remaining biomass of algae after oil extraction can be utilized as a renewable and sustainable resource for carbon. This can replace agriculture residues to produce biofuels such as ethanol and butanol[3]. Algae are known to produce biomass faster and on reduced land surface as compared with lignocellulosic biomass [4].

Recently, a $4^{\text {th }}$ generation biofuel has been proposed where the biofuels are created using petroleum-like hydroprocessing or advanced biochemistry. The $4^{\text {th }}$ generation of biofuels has introduced the concept of "cell factory". Studies on metabolic engineering of algae to increase the photosynthetic ability of the cell to produce higher yield of fuel has shown lots of potentials[5]. Joule Biotechnologies - the folks behind the unusual hybrid solar-biofuel technology - uses sunlight, waste $\mathrm{CO}_{2}$ and engineered microorganisms in a "solar converter" to create fuel[6].

Now, what future is holding for us? It is being concluded that by 2022 , eight percent of the global fuel volumes consumed by transportation will be biofuels. Right now, $1^{\text {st }}$ and $2^{\text {nd }}$ generations of biofuels account for $99 \%$ of the world's biofuel production. Interestingly, $1^{\text {st }}$ generation ethanol and biodiesel are the only commercially viable product. While lots of interest is heading towards algae, technological advances promise to be helpful in making the $3^{\text {rd }}$ and $4^{\text {th }}$ generation fuels commercially competitive and hopefully the future of transportation fuels.

\section{References}

1. Pabbi, S., Dhar, D. W., Bhatnagar, S. K., Saxena, A., \&Kraan, S. (2011) Feasibility of algal biomass for biodiesel production. Algae biofuel.Lundquist, T. J., Woertz, I. C., Quinn, N. W. T., \&Benemann, J. R. (2010). A realistic technology and engineering assessment of algae biofuel production. Energy Biosciences Institute 1

2. Potts, T., Du, J., Paul, M., May, P., Beitle, R., \&Hestekin, J. (2012). The production of butanol from Jamaica bay macro algae. EnvironmentalProgress \& Sustainable Energy31(1)

3. Lee, R. A., \& Lavoie, J. M. (2013). From first-to third-generation biofuels: Challenges of producing a commodity from a biomass of increasing complexity. Animal Frontiers3(2).

4. Lü, J., Sheahan, C., \& Fu, P. (2011). Metabolic engineering of algae for fourth generation biofuels production. Energy \& Environmental Science4(7).

5. Kagan, J. (2010). Third and Fourth Generation Biofuels: Technologies, Markets and Economics Through 2015.

${ }^{*}$ Corresponding author: Yaser Dahman ,Department of Chemical Engineering Ryerson University, Toronto, Ontario, Canada, Fax: 1 416-979-5083; Tel: 1416 979-5000 ext.4080; E-mail: ydahman@ryerson.ca

Received December 21, 2013; Accepted December 23, 2013; Published December 31, 2013

Citation: Dhaman Y, Roy P (2013) Challenges and Generations of Biofuels: Will Algae Fuel the World? Ferment Technol 2: 119. doi:10.4172/2167-7972.1000119

Copyright: (C) 2013 Dhaman Y, et al. This is an open-access article distributed under the terms of the Creative Commons Attribution License, which permits unrestricted use, distribution, and reproduction in any medium, provided the original author and source are credited. 